\title{
LITERATUROZNAWSTWO
}

\author{
Jurij Eabyncew \\ DOI: $10.15290 / \mathrm{bb} .2018 .10 .01$ \\ Rosyjska Akademia Nauk \\ Moskwa \\ https://orcid.org/0000-0002-7900-6143
}

\section{Непреходящие споры о Франциске Скорине, включая «беловежские», и необходимость подготовки новейшей библиографии работ о нем}

Франциск Скорина - писатель-философ, писатель-гуманист, выступивший перед своим народом с яркими патриотическими воззваниями, и одновременно глубокий психолог, лирик, сумевший рассказать людям о величайших тайнах мира. Наряду с многими книгами, в том числе им самим написанными, Скорина издал в своем переводе значительную часть Библии. Она стала первой печатной Библией у восточно- и южнославянских народов и вышла в свет почти за полстолетия до появления польских печатных Библий.

Франциск Скорина доверил бумаге такие сокровенные, выстраданные свои мысли, читающиеся теперь как некая абсолютная законченная формула духовного развития человека: Ecmь наивьлшшая мудрость розмышление смерти и познание самого себе ${ }^{1}$; Наиболей любовь ко всим да соблудает, еже есть совершена над все иные дарования, без нея же ничто проспешно есть ${ }^{2}$. Да совершен будет человек! - вслед за авторитетами древности восклицал Франциск Скорина ${ }^{3}$. Он стремился сделать все, чтобы его народ на родном языке мог постичь сокровенную мудрость человечества.

\footnotetext{
1 Книга Иова, Прага 1517, л. 2 об.

2 Коринфом перваго послания светого апостола Павла сказание доктором Франциском Скориною с Полочка, [в:] Апостол, Вильна 1525, л. 36 об. третьего счета.

3 Предословие в Псалтирь, [в:] Псалтырь, Прага 1517, л. 2.
} 
Как выдающийся европеец-гуманист Скорина страстно желал послужить общему делу духовного возрождения человека, его внутреннему совершенствованию. Этому и посвящены книги великого белоруса, воспринимающиеся сейчас как самая дорогая национальная реликвия, как духовное сокровище, национальная святыня, как символ всей тысячелетней белорусской культуры.

В силу исторических условий, в отличие от западноевропейских гуманистов, Скорина должен был весьма считаться с особой, веками узаконенной восточнославянской книжной традицией, которую, тем не менее, он значительно реформировал. Невозможность отойти в своем литературном творчестве на традиционном литературном языке церковнославянском - и даже на языке, близком к народному, от этой традиции (иначе он бы не был понят соотечественниками-современниками), вынуждает Скорину максимально опираться на нее, часто высказывать свои собственные суждения устами известных древних авторитетов.

Использование в творчестве чисто традиционных, восточных, начал и сплав их с западными дали необычайно интересный, оригинальнейший литературно-графический материал, ставящий в тупик при его рассмотрении не только современника Скорины, но и ученого наших дней. Рождающийся художественный образ заставляет одновременно помнить и о литературных особенностях Востока, и о достижениях графического искусства Запада, и о той общности культур, которая свойственна всей Европе. Вот почему невозможно отделить в творчестве Скорины эти две главнейшие европейские культурные традиции: традицию византийского Востока и традицию римского, латинского Запада. Франциск Скорина связал, замкнул их в своем творчестве. Об этом свидетельствуют не только сами тексты скорининских книг, но и их архитектоника, композиция, графика.

Величайшая заслуга Скорины в том, что он предназначает свои издания и сочинения не узкому кругу образованных лиц, пишет для них не на латинском языке, как это делает, например, Эразм Роттердамский, а, используя в основном традиционные литературные жанры и близкий к народному язык, создает народноязычные издания, предназначавшиеся всем людям без исключения. Книги Скорины - «четьи» - подобные тем, которые легли в основание многих европейских национальных литератур, имели конкретный читательский адрес.

Выпущенные им книги - это не просто переведенные или подготовленные к печати тексты, снабженные теми или иными комментариями. Книги Скорины - сложный комплекс сотен самых различных 
литературных произведений, написанных, переведенных или подготовленных им к изданию по канонам тогдашней европейской науки. Скорина как мастер слова предстает перед нами сразу в нескольких авторских ипостасях: писателя-прозаика, гимнографа и поэта, переводчика с нескольких древних и новых языков.

Книги Франциска Скорины выступают как единство содержания и его типографского воплощения, служащего своеобразным фоном и обрамлением главного в книге - слова, написанного или переведенного просветителем. Эта неразрывная связь прослеживается на всех уровнях, на примере всех элементов книг Скорины, включая даже мельчайшие.

Скорина-прозаик работал во многих жанрах, одни из которых были у нас традиционными, другие, и их едва ли не большинство, впервые введены в белорусскую, да и во все восточнославянские литературы именно им.

Сравнивая сделанное Скориной с творчеством его виднейших европейских современников, нельзя не отметить, что в отличие от многих из них он значительно опередил время, сознание своего народа. Лишь спустя столетия и его, Скорину, назовут великим. Он станет символом всей белорусской культуры. Его, Скорину, мы ценим за то, что литература на родном языке оказалась для него и средством, и целью, тем абсолютом, который мог указать людям истинный путь в жизни.

За свою жизнь Скорина объездил немало стран, учился в старейших европейских университетах, достиг высших ученых степеней, был доктором «семи свободных искусств» и доктором медицины. Все это дало ему возможность, как никому в восточном славянстве, сопоставить жизненные ценности Запада и Востока Европы, решить для себя и других, прежде всего для «братьев» своих «Руси», те многочисленные философско-гуманитарные, богословские и литературные проблемы, которые и на сегодняшний день все так же важны для нас.

Славянский мир еще при жизни Ф. Скорины во многом по достоинству оценил его деятельность. Несмотря на неканоничность переведенной и напечатанной им Библии, ее экземпляры получили широкую известность, преимущественно на Востоке Европы, у белорусов, русских, украинцев и славян, живущих в отрогах Карпат. Можно говорить даже о прямом влиянии Скорининской библии на украинскую литературу и прежде всего украинские библийные издания и рукописи, включая новозаветные. Поражают широта распространения и популярность книг Ф. Скорины на Московской Руси и в России. Именно в России произведениям Ф. Скорины суждена была наиболее долгая 
жизнь в читательской среде. Русские же старообрядцы переписывали и даже перепечатывали созданные им тексты вплоть до начала XX столетия.

Можно говорить и об особой авторитетности наследия Ф. Скорины среди протестантов Европы. Его книги оказали прямое влияние на Примуса Трубера, Симона Будного и деятельность известного Ильи Копиевича, сподвижника Петра I. В этой связи интересна оценка Ф. Скорины, данная ему в начале XVII века таким авторитетом греко-католической (униатской) церкви как Анастасий Селява, настоятель Виленского Свято-Троицкого базилианского монастыря: ... Скорина, по вероисповеданию гусит, который напечатал вам книги по руски в Праге. Принимали их с благодарностью, еще бы, ведь он называл себя Русином с Полочка. Восхваляли между собой его издания, человек достойный, говорили, и Русин, брат наш это печатал ${ }^{4}$.

Примечательно, что у восточных славян книги Ф. Скорины обращались не только в элитарной среде, но и среди крестьян. Примеров здесь много, особенно если иметь ввиду русское старообрядчество, благодаря которому до нас дошла значительная, если не большая часть экземпляров изданий Ф. Скорины.

Едва ли не самый яркий пример авторитетности литературного наследия Ф. Скорины для современников демонстрирует знаменитое украинское Пересопницкое евангелие 1556-1561 гг., на котором ныне присягают вступающие в должность президенты Украины. Евангелие это, написанное на Волыни, создано под непосредственным влиянием Скорининской библии 5 . Пожалуй, настоящую традицию составляет использование скорининского наследия в кругу старообрядчества. При этом Ф. Скорина выступает как авторитет древности и на него виднейшие представители старообрядчества различных согласий ссылаются в наиболее важных при доказательстве собственной правоты случаях. Находим мы ссылки на издания Ф. Скорины и в известных «Поморских ответах», созданных в глуши Русского Севера, на старообрядческом Выгу, в начале XVIII века.

Гуманитарная наука серьезно обратила свое внимание на издания Ф. Скорины, пожалуй, лишь в исходе XVIII столетия, хотя С. Рингельтаубе называет его «мастером слова» уже в 1744 году ${ }^{6}$. Приоритет

\footnotetext{
4 Anastazy Sielawa, Antelenchus, to iest Odpis..., Wilna 1622, s. 53.

5 П.В. Владимиров, Доктор Франциск Скорина: Его переводы, печатные издания и язык, СПб, 1888, с. 234-237.

6 S. Ringeltaube, Gründliche Nachricht von polnischen Bibeln..., Danzig 1744, s. 170.
} 
в этом принадлежит П. Алексееву, И. Штритеру, Д. Семенову-Рудневу (епископу Дамаскину), Й. Добровскому. Тем не менее еще и в середине XIX века М. Погодин имел все основания утверждать, что скорининское наследие никто у нас должным образом не изучает ${ }^{7}$. Книги Ф. Скорины были и оставались гордостью каждой библиотеки, как о том сообщалось в первом по времени отчете Московского публичного музея 1864 года $^{8}$, но широкого и всестороннего их изучения все же не проводилось вплоть до появления в 1888 году монографии П. Владимирова. Тогда же разгорается жаркий спор о конфессиональной принадлежности Ф. Скорины, причем первоначально появилось множество публикаций о католической ориентации белорусского просветителя 9 . Пожалуй, самая взвешенная оценка тех лет, остающаяся во многом справедливой и сейчас, принадлежала украинскому литературоведу А. Барвинскому, который считал Ф. Скорину в этом плане личностью загадочной ${ }^{10}$, в то время как его земляки-львовяне писали о Ф. Скорине - православном русине ${ }^{11}$ или же Скорине-католике ${ }^{12}$.

Постепенно Ф. Скориной начинает гордиться все ученое славянство вне зависимости от вероисповедных симпатий, хотя разноголосица мнений относительно связи его деятельности с какою-либо религиозной доктриной, как о том упоминал украинский историк М. Грушевский ${ }^{13}$, не стихает по сей день.

Впрочем, составить правильное всеобъемлющее представление обо всем этом сейчас просто невозможно. С начала 1990-х годов, момента постпразднования 500-летия со дня рождения Франциска Скорины, даты, конечно же, весьма условной, прекращены всякие усилия по подготовке текущей скориноведческой библиографии и потому мировая Scoriniana последнего тридцатилетия стала настоящей terra in-

7 М. Погодин, О приобретениях на Нижегородской ярмарке, "Московитянин" 1847 , ч. 3 , с. $120-122$.

8 Отчет по Московскому публичному музею от времени основания его до 1 января 1864 г., СПб, 1864, с. 31.

9 Белорусс, Судьбы русского языка в костелах Северо-Западного края, "Русский вестник" 1868, № 9, с. 143-144; И. Козловский, Библиографические редкости, хранящиеся в Виленской публичной библиотеке, [в:] Вестник Западной России, 1870, т. 1, кн. 3, с. 89; В.Ф. Василевский, Очерк истории города Вильнь, [в:] Памятники русской старины в западных губерниях империи, СПб 1872, вып. 5, с. 33.

10 Б. Ол, Библиография, "Правда" 1879, № 9, с. 590-592.

11 А. Вахнянин, О докторе Франциску Скорине и его литературной деятельности, Львов 1879 .

12 Ю.Б. Килька уваг..,, "Правда" 1879, № 10, с. 640-645.

13 М. Грушевський, Історія Украӥни-Руси, Київ-Львів 1907, т. 6, с. 428. 
cognita. K моменту полтысячелетнего юбилея белорусского книгопечатания, отмеченного в 2017 году, известные библиографии работ о жизни и деятельности Франциска Скорины В. Тумаша ${ }^{14}$, Е. Немировского и Л. Осипчик ${ }^{15}$, В. Гришкевич и Л. Юревича ${ }^{16}$ так и не были продолжены и дополнены. Иными словами, исследователям, в том числе и специально занимающимся изучением белорусской книжности и литературы, остаются в большинстве неизвестны сотни и даже тысячи работ последних десятилетий, так или иначе связанных со Скориной и его наследием. Особенно наглядно подчеркивает этот факт выпущенная в самом конце 2017 года энциклопедия «Францыск Скарына» 17 , составленная за весьма короткий срок в невероятной спешке.

Отношение самих белорусов к образу Франциска Скорины и его книгам в те или иные времена - предмет особого изучения. И белорусская Белосточчина (белорусское Подляшье) представляет в этом специальный интерес, имея ввиду явную национально-религиозную слитность здешнего белорусского населения. В кругу белорусов Польши Скорина наиболее известен, конечно же, в среде гуманитарной интеллигенции, учителей, писателей, журналистов, ученых. Отсутствие общей библиографической картины мирового скориноведения последних десятилетий привело к тому, что создателями указанной выше энциклопедии «Францыск Скарына» 2017 года было упущено даже имя такого выдающегося скориноведа наших дней как краковский профессор А. Наумов, тесно связанный с Подляшьем, где в Бельске Подляшском похоронен его отец, известный протоиерей Евгений Наумов.

О своей кровной связи с белорусским Подляшьем А. Наумов не забывает никогда: Do Krakowa przyjechałem przed czterdziestu... laty z Podlasia, jako "popowicz", syn ojca Eugeniusza, stużacego wtedy w parafii Narodzenia Bogarodzicy w Bielsku Podlaskim ${ }^{18}$. Многолетняя и многогранная активная исследовательская и организационная деятельность в области скориноведения А. Наумова, создавшего в Польше своего рода научную школу, охватившую разные ее уголки, наладившего совместные постоянные научные контакты и с ведущими учеными Литвы, зани-

14 V. Tumash, Five Centuries of Scoriniana XVI-XX, New York 1989.

15 Францьск Скарына: Жиъчиё $і$ дзейнасць. Паказальнік літаратурь, Мінск 1990.

16 Францыск Скарына: Жьциё $і$ дзейнасць. Паказальнік літаратуры. Дадаткі за 1550-1988 ге., 1989-1993 ге., Мінск 1995.

17 Францыск Скарына: Энцыклапедыля, Мінск 2017.

18 Nowa szkoła: Z Aleksandrem Naumowem... rozmawia Anna Radziukiewicz, "Przegląd Prawosławny" 2004, № 5, s. 15. 
мающимися проблемами культурно-языкового наследия Великого княжества Литовского, по сути, уникальна. Став в 2003 году университетским профессором в Венеции, он не только не теряет постоянную связь с родиной, но и является здесь инициатором и исполнителем многих крупных научных проектов в сфере гуманитаристики, включая непосредственно связанные с Франциском Скориной. $\mathrm{K}$ их числу относится и такое огромное многолетнее начинание как создание сводного каталога церковнославянских рукописей, хранящихся в современной Польше. В нем, в частности, описаны ценнейшие списки скорининского виленского Апостола 1525 года, происходящие из разных мест Галиции, относящиеся к XVI - началу XVII веков ${ }^{19}$. Интерес к Франциску Скорине возник у А. Наумова довольно давно, но особенно важные его работы о нем появились в последние годы. При этом в центре внимания профессора как переводческая, так и издательская деятельность Франциска Скорины. Он же автор ряда обобщающих исследований, которые могут быть отнесены к разряду интегрального скориноведения ${ }^{20}$. Было бы справедливым процитировать одно из самых емких итоговых его суждений о Франциске Скорине:

Франциск Скорина первый в восточнославянской письменности предлагает не только собственные и отредактированные переводы и мелкие к ним комментарии, но дает своему читателю, которого любит и уважает и которому желает вечного спасения и радеет о нем, обильные и подробные объяснения о структуре Библии, об отличиях и связях между различными вариантами переводов, указывая на авторитет блаж. Иеронима, говорит о Библии как о знаковой системе, ее универсальности и многофункциональности. Его задача не спорить с другими, не доказывать свою правоту, но дать милой русинской братии, по примеру некоторых других, но все еще немногих народов, самый полный и самый полезный текст Священного Писания. Он предстает перед нами как человек, продолжающий самые лучшие традиции христианской библеистики. Высокое самочувствие Скорины как служителя истины, его широкое библейское знание, глубокая привязанность к вере христианской без конфессионального определения и своему руському роду придают его незаконченному начинанию особый характер, благодаря которому занимает оно исключительное место в истории славянской словесности и культуры ${ }^{21}$.

19 A. Naumow, A. Kaszlej, Rękopisy cerkiewnostowiańskie w Polsce: Katalog, wyd. 2. Kraków 2004. № 48, 62, 71, 92.

20 A. Naumow, Rusin na szlakach renesansowej Europy [w:] Franciszek Skoryna z Polocka: Zycie i pisma, Gniezno 2007, s. 9-36.

21 А.Е. Наумов, Переводы Франциска Скоринь в контексте черковнославянского перевода Библии, "Cerkiewny wiestnik" 2009, № 3, s. 52. 
Знаменательна инициатива А. Наумова в подготовке и издании польскоязычных переводов сочинений Франциска Скорины - случай этот пока в мировом скориноведении практически единственный. $\mathrm{K}$ ее реализации он шел долгие годы ${ }^{22}$ и в 2007 году вместе с познанским профессором М. Волчак-Миколайчаковой опубликовал польскоязычное собрание сочинений Франциска Скорины в третьем томе издательской серии «Biblioteka Duchowości Europejskiej» ${ }^{23}$, основанной его активными стараниями.

В самое недавнее время А. Наумов опубликовал ряд работ о Франциске Скорине, которые содержат много новых принципиальных наблюдений над его наследием как библеиста ${ }^{24}$, издателя ${ }^{25}$, переводчика ${ }^{26}$, просветителя «Rusi polsko-litewskiej w XVI wieku» ${ }^{27}$. Последняя работа интересна прежде всего конкретным аналитическим отображением места библеистической деятельности Франциска Скорины в пространстве белорусских и украинских земель древней Руси. При этом автор поднимает и решает принципиальный вопрос о том, каким образом русинь были в состоянии связать традичионную духовность c ренессансной philologia sacra ${ }^{28}$. Следует заметить, что именно этот аспект пытаются проследить в своих исследованиях и наиболее талантливые ученики профессора, среди которых выделяется его краковский преемник Я. Страдомский, автор специальной монографии о церковнославянской литературной культуре Великого княжества Литовского 29. Несомненное влияние на успех скориноведческих исследований варшавского кодиколога А. Кашлея оказала его многолетняя совместная работа с А. Наумовым. Для этого достаточно сравнить одни из первых его

22 A. Naumow, Czy język jest konfesyjny? Uwagi przy przekladaniu Franciszka Skoryny [w:] Roczniki Humanistyczne, t. 43, 1995, № 7, s. 33-41.

23 Franciszek Skoryna z Polocka: Życie i pisma, Gniezno 2007.

24 A. Naumow, Franciszek Skoryna z Polocka jako biblista [в:] Cредновековието в огледалото на един филолог: Сборник в чест на Светлина Николова, София 2009, c. $166-173$.

25 А. Наумов, Aпостол Франциска Скоринь и его судьбь [в:] Studies on language and culture in Central and Eastern Europe 21: Славянский Апостол: История текста и язык, München 2013, s. 185-194.

26 А. Наумов, Переводы Франциска Скорины в контексте черковнославянского перевода Библии [в:] Translation and tradition in Slavia Orthodoxa, Wien 2012, s. 10-25. 27 A. Naumow, Biblia w kulturze Rusi polsko-litewskiej w XVI wieku, "Slavia Meridionalis" 2016, № 16, s. 32-51.

28 Там же, с. 50.

29 Jan Stradomski, Rękopisy i teksty: Studia nad cerkiewnostowiańska kultura literacka Wielkiego Księstwa Litewskiego i Korony Polskiej do końca XVI wieku, Kraków 2014. 
наблюдений над списками скорининских книг ${ }^{30}$ с их описанием в прекрасном объемном каталоге, вышедшем много позднее, всего несколько лет назад ${ }^{31}$.

Еще один польский профессор, пишущий о Франциске Скорине, 3. Ярошевич-Переславцев - белоруска с Подляшья, которая в первую очередь интересовалась виленским периодом его деятельности ${ }^{32}$. Скончавшийся в 2016 году в Минске литературовед В. Казберук, белорус из подляшской вёски Бандары, связавший свою жизнь со столицей Беларуси и ее Академией наук, написал о Скорине даже книгу для школьников ${ }^{33}$, правда, при этом о нем также нет сведений в упоминавшейся энциклопедии «Францыск Скарына» 2017 года. Друг самых именитых членов и создателей литературного объединения «Белавежа», односельчанин и родственник профессора А. Барщевского (Алеся Барского) В. Казберук печатал свои работы о Скорине и на Белосточчине, о белорусской литературной жизни которой до сих пор весьма памятны его слова: ...беларуская літаратура Беласточчьны - 3'ява фенаменальная. Прачуюиь там $і$ пішуць толькі энтузіястьи, небьвала самаахвярныя $i$ адданыл справе беларушчыны. Я ўпэўнень, што настане пара, калі іх заслугі $i$ уся дзейнасць будущь належным чьнам ацэненьз ${ }^{34}$. Важной для своего времени публикацией В. Казберука о Франциске Скорине, увы, не учтенной в библиографии В. Гришкевич и Л. Юревича 1995 года, была достаточно объемная статья, вышедшая в 1991 году в Белостоке ${ }^{35}$. Тогда же часть этого текста опубликовали на польском языке в журнале «Kamena»36.

Едва ли не самый активный и заслуженный скориновед из нынешних «беловежцев» А. Барщевский, к сожалению, никак не упомянутый

30 A. Kaszlej, Wplyw cerkiewnosłowiańskiej ksiażki drukowanej na rękopiśmienna (na podstawie zbiorów Biblioteki Narodowej w Warszawie), [w:] Rękopis a druk, Kraków 1993, s. $167-178$.

31 A. Kaszlej, Inwentarz rękopisów Biblioteki Kapituły Greckokatolickiej w Przemyślu w zbiorach Biblioteki Narodowej, Warszawa 2011.

32 Ю.А. Лабынцев, Л.Л. Щавинская, Современное польское скориноведение, [в:] Матэрыяльи Міжнароднага кангрэса 500 гадоў беларускага кнігадрукавання, ч. 1. ХІІІ Міжнародныя кнігазнаўчыя чытанні. Мінск, 14-15 верасня, Мінск 2017, c. $67-72$.

33 У. Казбярук, Францішак Скарына: навукова-папулярны нарыс, Мінск 2003.

34 У. Казбярук, «Беларуская літаратура Беласточчыны - з'ява фенаменальная», "Ніва" 11 лістапада 2007, № 45.

35 У. Казбярук, Веліч здзяйсненняў Францішка Скарыны, [у:] Беларускі каляндар 1991, Беласток 1991, с. 127-135.

36 W. Kazbiaruk, Ja Franciszek, syn Skaryny z Polocka, "Kamena" 1991, № 1, s. 10-12. 
в энциклопедии «Францыск Скарына» 2017 года, автор целого ряда различного рода работ о Скорине, в том числе научных, научно-популярных, художественных. Вместе с аналогичными работами других «беловежцев» выстраивается, без сомнения, особая Scoriniana былых и нынешних членов литературного объединения, нуждающихся в специальном библиографировании, что сделать совсем не просто, особенно, если учесть общий объем написанного ими и отсутствие на момент празднования 60-летнего юбилея «Белавежы» хотя бы общей обзорной библиографии только отдельных изданий. Председатель правления «Белавежы» профессор Я. Чиквин справедливо говорит, что колькасць паасобных твораў «беловежиев» застаециа па сутнасиі ўжо непалічальная ${ }^{37}$.

Мне вспоминаются мои достаточно многочисленные разговоры о Скорине в различных местах Польши и Беларуси, в том числе и у них дома с некоторыми «беловежцами», прежде всего Н. Гайдуком и С. Яновичем, всегда живо интересовавшимися судьбой великого полоцкого уроженца и писавших о нем. Много сделавший для развития белорусского народного образования в Польше, Н. Гайдук писал о Скорине и для детей и для взрослых, всегда называя своего героя слайным сынам беларускай зямлізі. Ему же принадлежит и рецензия на очень важный в истории скориноведения научный сборник «Белорусский просветитель Франциск Скорина и начало книгопечатания в Белоруссии и Литве» (Москва, 1979), озаглавленная «Скарына на Падляссі?»39, что было связано, в частности, с моими разысканиями скорининского книжного наследия в библиотеке Супрасльского монастыря.

Часто вспоминал о скорининских темах и С. Янович, который рассказывал мне со свойственным ему юмором и о том, как он приобщился к скориноведению еще в начале 1950-х годов, почти еще в детском возрасте. Вот как о том же, но более лапидарно писал С. Янович в своей известной публицистической книге «Białoruś, Białoruś»:

Inicjując w lipcu 1953 roku trochę filomacką imprezę, Sajuz Biełaruskich Patryjotaú (Związek Patriotów Białoruskich), wiedziałem, że krakowska Alma Mater ukończył i uzyskał w niej tytuł doktora nauk wyzwolonych Franciszek Skaryna, syn kupecki z Połacka (Połocka) i ojciec Renesansu na Białorusi. Wygłosilem wtedy o nim referat, w przedżniwną niedzielę upalnego lata na pod-

37 М. Лукша, «Белавежа» «Biełowieża», "Ніва" 2017, № 49.

38 М. Гайдук, Слайны сын беларускай зямлі, [у:] Беларускі каляндар на 1967 год, Беласток 1967, с. 33-36.

39 М. Гайдук, Скарына на Падляссі?, "Ніва” 1980, № 37. 
daszu pożydowskiej chaty, u Hryszy Harbuza, w moich cudownych Krynkach; mówiłem do kilku kółkowiczów z tamtych początków insurekcji kulturalnej polskich Białorusinów. Kto wie - gadaliśmy - czy Skaryna nie przejeżdżał ongiś akurat przez Krynki, to miasto zygmuntowskie na szlaku z Litwy do Korony? ${ }^{40}$

Среди заметок о Скорине, рассыпанных в книгах С. Яновича, есть одна, очень точная и необычайно актуальная, роднящая его взгляд с приведенным выше мнением более чем столетней давности М. Грушевского: Poniewa $\dot{z}$ żadna z orientacji konfesyjnych w obecnym życiu duchownym Białorusi nie jest w stanie zlekceważyc zastug narodowych Franciszka Skaryny, nie ustaje dyskusja nad jego przynależnościa wyznaniowa ${ }^{41}$.

Более молодые поколения «беловежцев» и польских белорусистов в своих изданиях продолжают отдавать должное скорининской проблематике. Здесь прежде всего нужно назвать профессора Г. Тваранович, для которой, кстати, образ Скорины стал судьбоносным в ее личной жизни. Как признавалась она сама: У верасні 1990-га года на Cкарынаўскіх святах я пазнаёмілася з Янам Чыквіньлм... ${ }^{42}$.

По сей день Франциск Скорина остается для литераторов-«беловежцев» одним из основателей той единой национально-культурной традиции, которая объединяет всех белорусов по обе стороны границы. По словам Я. Чиквина:

Пісьменнікі "Белавежы" сапраўды шчыльна запоўнілі сваю этнічную прастору культурна-эстэтычным зместам. 3 пойным правам можна сказаць, што другая палова XX стагоддзя належыць у беластоцкім краі найперш "белавежцам". Самадастатковасць і унікальнасць "Белавежы" - не толькі ў тым, што гэта адзіная ў гісторы Беларусі, па-за яе дзяржаўнымі межамі, творчая арганізацыя са знакам шматгадовай нацыянальнай духойнай культуры. Яе выключная каштоўнасць таксама і ў тым, што беларускія пісьменнікі Польшчы сваім жыццёвым вопытам і пісьменніцкай дзейнасцю наследуюць спаконную культурна-духойную традыцыю Беларусі: тую, якая фарміравалася Кірылам Тураўскім, Ефрасінняй Полацкай, Францішкам Скарынам i, урэшце, супрасль-заблудаўскімі кніжнікамі, асветнікамі. Творчасць "белавежцаў" - асабліва адметная і таму, што яна, у першую чаргу, беларуская, а не савецка-беларуская, і таму, што яна ад пачатку свабодная ў творчым самавыяўленні ${ }^{43}$.

40 S. Janowicz, Białoruś, Białoruś, Warszawa 1987, s. 9.

41 S. Janowicz, Terra incognita: Białoruś, Białystok 1993, s. 49.

42 Г. Тварановіч, Шлях да Бога, "Przegląd Prawosławny", 1994, № 11, с. 20.

43 Я. Ч. Пасляслоўе, [у:] Шлях па прамой часу: Да гісторыі беларускай літаратуры Польшчь 1958 - 2008 ге., Беласток 2007, с. 317. 


\section{I T E R A T U R A}

Â. Č., Paslâsloy̆e, [u:] Šlâh pa pramoj času: Da gistoryi belaruskaj litaratury Pol'ščy 1958-2008 gg., Belastok 2007 [Я. Ч., Пасляслоўе, [y:] Шлях па прамой часу: Да гісторьі беларускай літаратурь Польшчь 1958-2008 г2., Беласток 2007].

Белорусс, Sud'by russkogo âzyka v kostelah Severo-Zapadnogo krâa, "Russkij vestnik" 1868, № 9; Kozłowskij B., Bibliografičeskie redkosti, hranâŝiesâ v Vilenskoj publičnoj biblioteke, [v:] Vestnik zapadnoj Rossii, 1870, t. 1, kn. 3; Vasilevskij, V.F., Očerk istorii goroda Vil'ny, [v:] Pamâtniki russkoj stariny v zapadnyh guberniâh imperii istorii goroda Vil'ny, SPB 1872, vyp. 5] [Белорусс, Судьбы русского языка в костелах Северо-Западного края, "Русский вестник" 1868, № 9; Козловский Б., Библиографические редкости, хранящиеся в Виленской публичной библиотеке, [в:] Вестник Западной России, 1870, т. 1, кн. 3; Василевский В.Ф., Очерк истории города Вильны, [в:] Памятники русской старинь в западных губерниях империи истории города Вильньи, СПб 1872, вып. 5].

Franciszek Skoryna z Połocka: Życie i pisma, Gniezno 2007.

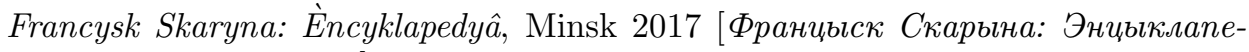
дbls, Мiнск 2017].

Francysk Skaryna: Žyccë i dzejnasc'. Pakazal'nik litaratury, Minsk 1990 [Францьск Скарына: Жиьщиё і дзейнасць. Паказальнік літаратурь, Мінск 1990].

Francysk Skaryna: Žyccë $i$ dzejnasc'. Pakazal'nik litaratury. Dadatki za 15501988 gg., 1989-1993 gg., Minsk 1995 [Францыск Скарына: Жыичё $і$ дзейнасць. Паказальнік літаратуры. Дадаткі за 1550-1988 ге., 1989 1993 ге., Мінск 1995].

Gajduk M., Skaryna na Padlâssi?, "Niva" 1980, № 37 [М. Гайдук, Скарынна на Падляссі?, "Ніва" 1980, № 37].

Gajduk M., Slay̆ny syn belaruskaj zâmli, [u:] Belaruski kalândar na 1967 god, Belastok 1967 [М. Гайдук, Слаўны сын беларускай зямлі, [y:] Беларускі каляндар на 1967 год, Беласток 1967].

Gruševs'kij M., Istoriâ Ukrä̈ny-Rusy, Kï̈-L'viv 1907, t. 6 [Грушевський М., Історія України-Руси, Київ-Львів 1907, т. 6].

Janowicz S., Białoruś, Białoruś, Warszawa 1987.

Janowicz S., Terra incognita: Białoruś, Białystok 1993.

Kaszlej A., Inwentarz rękopisów Biblioteki Kapituły Greckokatolickiej w Przemyślu w zbiorach Biblioteki Narodowej, Warszawa 2011.

Kaszlej A., Wpływ cerkiewnosłowiańskiej ksiażki drukowanej na rękopiśmienna (na podstawie zbiorów Biblioteki Narodowej w Warszawie), [w:] Rękopis a druk, Kraków 1993. 
Kazbâruk U., «Belaruskâ̂ litaratura Belastoččyny - z'âva fenamenal'naâ», "Niva" 2007, № 45 [У. Казбярук, «Беларуская літаратура Беласточчьны 3'ява фенаменальная», "Ніва" 11 лістапада 2007, № 45].

Kazbâruk U., Francišak Skaryna: navukova-papulârny narys, Minsk 2003 [Казбярук У., Францішак Скарьън: навукова-папулярны нарыс, Мінск 2003].

Kazbâruk U., Velič zdzâjsnennây̆ Franciška Skaryny, [u:] Belaruski kalândar 1991. Belastok 1991 [У. Казбярук, Веліч здзяйсненняў Францішка Скарыны, [у:] Беларускі каляндар 1991, Беласток 1991].

Kazbiaruk W., Ja Franciszak, syn Skaryny z Polocka, "Kamena" 1991, № 1.

Kniga Iova, Praga 1517.

Korinfom pervago poslaniâ svetogo apostola Pavlaskazanie doktorom Franciskom Skorinoû s Polocka, [v:] Apostol, Vil'na 1525 [Коринфом перваго послания светого апостола Павла сказание доктором Франииском Скориною с Полочка, [в:] Апостол, Вильна 1525, л. 36 об. третьего счета].

Kozlovskij I., Bibliografičeskie redkosti, hranâŝiesâ v Vilenskoj publičnoj biblioteke, [v:] Vestnik Zapadnoj Rossii, 1870, t. 1, kn. 3 [Козловский, И., Библиографические редкости, хранящиеся в Виленской публичной библиотеке, (в:) Вестник Западной России, 1870, т. 1, кн. 3].

Labyntsev Ju.A., Shchavinskaja L.L., Sovremennoe pol'skoe skorinovedenie, [v:] Matèryâly Mižnarodnaga kangrèsa 500 gadoy̆ belaruskaga knigadrukavannâ. Č. 1. XIII Mižnarodnyâ knigaznay̌čyâ čytanni. Minsk, 14-15 verasnâ. Minsk 2017 [Лабынцев, Ю.А., Щавинская, Л.Л., Современное польское скориноведение, [в:] Матэрыяль Міжнароднага кангрэса 500 гадоў беларускага кнігадрукавання, ч. 1. ХІІІ Міжнародныя кнігазнаўчыя чытанні. Мінск, 14-15 верасня, Мінск 2017]

Lukša M., «Belaveža» «Biełowieża», "Niva” 2017, № 49 [Лукша M., «Белавежа» «Biełowieża», "Ніва" 2017, № 49].

Naumov A., Apostol Franciska Skoriny i ego sud'by, [v:] Studies on language and culture in Central and Eastern Europe 21: Slavânskij Apostol: Istoriâ teksta $i$ âzyk, München 2013.

Naumov A., Perevody Franciska Skoriny v kontekste cerkovnoslavânskogo perevoda Biblii, [v:] Translation and tradition in Slavia Orthodoxa, Wien 2012 [Haумов, А., Переводь Франциска Скоринь в контексте иерковнославянского перевода Библии, [в:] Translation and tradition in Slavia Orthodoxa, Wien 2012].

Naumov A.E., Perevody Franciska Skoriny v kontekste cerkovnoslavânskogo perevoda Biblii, "Cerkiewny wiestnik" 2009, № 3 [Наумов, А.Е., Переводы Франциска Скорины в контексте иерковнославянского перевода Библиu, "Cerkiewny wiestnik" 2009, № 3].

Naumow A., Biblia w kulturze Rusi polsko-litewskiej w XVI wieku, "Slavia Meridionalis" 2016, № 16. 
Naumow A., Czy język jest konfesyjny? Uwagi przy przekładaniu Franciszka Skoryny, [w:] Roczniki Humanistyczne, t. 43, 1995, № 7.

Naumow A., Franciszek Skoryna z Połocka jako biblista, [v:] Srednovekovieto v ogledaloto na edin filolog: Sbornik v čest na Svetlina Nikolova, Sofiâ 2009.

Naumow A., Kaszlej A., Rękopisy cerkiewnosłowiańskie w Polsce: Katalog. Wyd. 2, Kraków 2004.

Naumow A., Rusin na szlakach renesansowej Europy, [w:] Franciszek Skoryna z Potocka: Zycie i pisma, Gniezno 2007.

Nowa szkoła: Z Aleksandrem Naumowem... rozmawia Anna Radziukiewicz, "Przegląd Prawosławny" 2004, № 5.

Ol. B., Bibliografîิ, "Pravda" 1879, № 9. [Ол, Б., Библиография, "Правда" 1879, № 9].

Otčet po Moskovskomu publičnomu muzêิ ot vremeni osnovaniâ ego do 1 ânvarâ 1864 g., SPb 1864 [Отчет по Московскому публичному музею от времени основания его до 1 января 1864 г., СПб, 1864].

Pogodin M., O priobreteniâh na Nižegorodskoj ârmarke, [v:] Moskovitânin, 1847, с̌. 3 [М. Погодин, О приобретениях на Нижегородской ярмарке, "Московитянин" 1847, ч. 3].

Predoslovie v Psaltir', [v:] Psaltyr', Praga 1517 [Предословие в Псалтирь, [в:] Псалтьирь, Прага 1517].

Ringeltaube S., Gründliche Nachricht von polnischen Bibeln..., Danzig 1744.

Sielawa Anastazy, Antelenchus, to iest Odpis..., Wilna 1622.

Stradomski J., Rękopisy i teksty: Studia nad cerkiewnosłowiańska kultura literacka Wielkiego Księstwa Litewskiego i Korony Polskiej do końca XVI wieku, Kraków 2014.

Tumash V., Five Centuries of Scoriniana XVI-XX, New York 1989.

Tvaranovič G., Šlâh da Boga, "Przegląd Prawosławny" 1994, № 11 [Тварановіч Г., Шлях да Бога, "Przegląd Prawosławny", 1994, № 11].

Û. B., Kil’ka uvag..., "Pravda" 1879, № 10 [Ю.Б., Килька уваг..., "Правда" 1879, № 10].

Vahnânin A., O doktore Francisku Skorine i ego literaturnoj deâtel'nosti, L'vov 1879 [Вахнянин А., О докторе Франииску Скорине и его литературной деятельности, Львов 1879].

Vasilevskij V.F., Očerk istorii goroda Vil'ny, [v:] Pamâtniki russkoj stariny $v$ zapadnyh guberniâh imperii, SPb 1872, vyp. 5 [Василевский, В.Ф., Очерк истории города Вильнь, [в:] Памятники русской старины в западньх губерниях империи, СПб 1872, вып. 5].

Vladimirov P.V., Doktor Francisk Skorina: Ego perevody, pečatnye izdaniâ i âzyk, SPB 1888 [Владимиров, П.В., Доктор Франииск Скорина: Его переводы, печатные издания и язык, СПб 1888]. 


\title{
S U M M A R Y
}

\author{
THE ENDLESS DEBATE ABOUT FRANCYSK SKARYNA, \\ INCLUDING THE "BELAVEZHA" LITERARY ASSOCIATION, \\ AND THE NEED TO PREPARE HIS LATEST BIBLIOGRAPHY
}

The article discusses the need to prepare Francysk Skaryna's latest bibliography. The importance of a comprehensive account of printed materials has been shown on the example of Skaryniana members of the Belarusian Literature Association "Belavezha" and Polish researchers of Belarus. The author believes that without these materials it is impossible to create a correct image of modern world-wide Skaryniana studies.

Key words: Francysk Skaryna, Skaryniana, the Belarusian Literature Association "Belavezha".

\section{S T R E S Z Z E N I E}

\section{SPORY NA TEMAT FRANCISZKA SKARYNY I NAJNOWSZEJ BIBLIOGRAFII JEGO TWÓRCZOŚCI}

W artykule wskazano na potrzebe przygotowania najnowszej bibliografii prac Franciszka Skaryny. Wykorzystując opracowania dotyczące jego twórczości przygotowane przez członków Białoruskiego Stowarzyszenia Literackiego „Białowieża” i polskich białorutenistów, autor artykułu podkreśla znaczenie opracowania wyczerpującej bibliografii prac Skaryny, bez której trudno stworzyć prawidłowy obraz współczesnych, światowych badań jego twórczości.

Słowa kluczowe: Franciszek Skaryna, Skoryniana, Białoruskie Stowarzyszenie Literackie „Białowieża”. 